\title{
Korelasi Minat Baca Dengan Kemampuan Membaca Permulaan Siswa Kelas III Sekolah Dasar Negeri 1 Seteluk
}

\author{
Isnaini $^{1^{*}}$, Safruddin ${ }^{2}$, Heri Setiawan ${ }^{3}$ \\ ${ }^{123}$ Pendidikan Guru Sekolah dasar, Jurusan Ilmu Pendidikan, FKIP,Universitas Mataram \\ Corresponding Author: iisnaini277@gmail.com ${ }^{1 *}$
}

\begin{abstract}
Abstrcat
This study aims to find out the correlation of reading interest with the initial reading ability of students in SDN 1 Seteluk, through a quantitative approach with correlation's research type. The sample technique uses non probability sampling in the form of saturated sampling techniques by taking the entire population, namely students of Class III SDN 1 Setuk. Data collection methods is using questionnaires to collect reading interest data and tests to measure initial reading ability. Data analysis techniques use descriptive statistical analysis and product moment correlation analysis. The results of the correlation test with the product moment showed that the efficacy of the correlation was 0.99. The results showed that there was a very strong positive correlation between reading interest and the initial reading ability of Class III Students of SDN 1 Seteluk. This is seen from the large keofesien correlation of 0.99 which is at intervals of 0.80-1 which means a very strong correlation. The positive is very strong judging from the increase in each variable, namely an increase in reading interest (variable X) by $54 \%$ and an increase in the ability to read startups (variable Y) by 83\%. And the results of the hypothesis test price t_hitung > t_tabel $(4.95>2,074)$ with a level of significance of $5 \%$ with the amount $N=24$. This means that Ho was rejected and Ha accepted. With this research, in the future it is expected to be one of the references to add insight to readers, especially related parties so as to increase reading interest in students so that the ability to read the beginning increases so that it is easy to receive further learning to maximize the potential it has as one of the educational goals.
\end{abstract}

Keywords: reading interest, initial reading ability.

\begin{abstract}
Abstrak
Penelitian ini bertujuan untuk mengetahui korelasi minat baca dengan kemampuan membaca prmulaan siswa kelas III Sekolah Dasar Negeri 1 Seteluk, melalui pendekatan kuantitatif dengan jenis penelitian korelasi. Teknik sampel menggunakan non probability sampling berupa teknik sampling jenuh dengan mengambil seluruh populasi, yakni siswa Kelas III SDN 1 Seteluk. Metode pengumpulan data dalam menggunakan angket untuk mengumpulkan data minat baca dan tes untuk mengukur kemampuan membaca permulaan. Adapun, teknik analisis data menggunakan analisis statistik deskriptif dan analisis korelasi product moment. Hasil pengujian korelasi dengan product moment menunjukan bahwa keofesien korelasi sebesar 0,99. Hasil tersebut menunjukan bahwa adanya korelasi positif sangat kuat antara minat baca dengan kemampuan membaca permulaan Siswa Kelas III Sekolah Dasar Negeri 1 Seteluk. Hal ini dilihat dari besar keofesien korelasi 0,99 yang berada pada interval 0,80-1 yang mengartikan korelasi sangat kuat. Adapun positif sangat kuat dilihat dari kenaikan masing-masing variabel yaitu kenaikan minat baca (variabel X) sebesar 54\% dan kenaikan kemampuan membaca permulaan (variabel Y) sebesar 83\%. Dan hasil pengujian hipotesis harga $t_{\text {hitung }}>t_{\text {tabel }}$ ( 4,95 $>2,074$ ) dengan taraf signifikansi sebesar 5\% dengan jumlah $\mathrm{N}=24$. Hal ini mengartikan bahwa Ho ditolak dan Ha diterima. Dengan adanya penelitian ini, kedepannya diharapkan dapat menjadi salah satu refrensi untuk menambah wawasan pembaca terutama pihak terkait sehingga mampu meningkatkan minat baca pada siswa agar kemampuan membaca permulaannya meningkat sehingga mudah menerima pembelajaran selanjutnya guna memaksimalkan potensi yang dimilikinya sebagai salah satu tujuan pendidikan.
\end{abstract}

Kata Kunci : minat baca, kemampuan membaca permulaan.

\section{PENDAHULUAN}

Bahasa merupakan salah satu kebutuhan manusia. Melalui bahasa manusia dapat berkomunikasi dengan sesama dan dapat menyampaikan hasil pemikiran, sikap dan perasaan antar sesama. Dalam dunia pendidikan bahasa memegang peranan penting sehingga perlu diajarkan pada setiap jenjang pendidikan. Pembelajaran bahasa mulai diajarkan pada jenjang pendidikan dasar, menengah hingga perguruan tinggi. Hal ini dikarenakan pembelajaran Bahasa Indonesia merupakan salah satu mata pelajaran yang wajib bagi siswa maupun mahasiswa.

Pembelajaran Bahasa Indonesia di Sekolah Dasar menekankan pada keterampilan berbahasa yang baik dan benar. Keterampilan berbahasa terdiri dari empat komponen yaitu keterampilan menyimak, 
berbicara, membaca, dan menulis. Keempat komponen berbahasa tersebut diharapkan mampu dikuasai oleh siswa Sekolah Dasar. Keempat keterampilan tersebut berperan penting dalam berkomunikasi, salah satunya adalah keterampilan membaca. Membaca merupakan kemampuan dasar yang harus dimiliki siswa dalam proses pembelajaran, artinya siswa dapat memahami materi pelajaran yang mereka ikuti melalui kegiatan membaca.

Kemampuan membaca penting dimiliki oleh siswa karena dapat membuka wawasan baru. Rahim (2008:1) menyatakan bahwa masyarakat yang gemar membaca dapat memperoleh pengetahuan dan wawasan baru sehingga mereka lebih siap menghadapi tantangan di masa depan. Kemampuan membaca merupakan salah satu kunci keberhasilan siswa dalam meraih kemajuan. Siswa yang memiliki kemampuan membaca tinggi akan lebih mudah mendapatkan informasi dari berbagai sumber tertulis seperti buku, media cetak maupun media elektronik.

Pembelajaran membaca di Sekolah Dasar terbagi kedalam dua tingkatan yaitu membaca permulaan dan membaca lanjutan. Kemampuan membaca permulaan merupakan kemampuan yang dimiliki oleh seorang siswa dalam memahami lambang dan simbol tulisan menjadi bunyi, sehingga mampu menerjemahkan kedalam sebuah kata yang memiliki makna. Menurut Baraja (dalam Anggraeni dan Alpian, 2020 :12) membaca permulaan merupakan suatu kegiatan mengenal lambang-lambang, bunyi, bahasa dan rangkaian huruf, kemudian menghubungkan dengan makna tertentu.

Kemampuan membaca permulaan ini penting bagi siswa sekolah dasar khususnya bagi siswa kelas rendah (I, II, dan III) karena sebagai dasar mereka untuk bisa memahami makna dari isi pelajaran. Sehingga dengan demikian siswa yang sudah bisa membaca permulaan mudah untuk memahami pelajaran selanjutnya. Rahmatika dkk, (2019:24) menyatakan bahwa kemampuan membaca permulaan merupakan salah satu kemampuan penting yang perlu dikuasai anak ketika memasuki pendidikan lanjut karena jika anak tidak menguasai hal tersebut, mereka akan mengalami kesulitan untuk memahami isi dari suatu bacaan sehingga berpengaruh pada proses pembelajaran selanjutnya. Namun, siswa yang tidak memahami pentingnya membaca tidak akan termotivasi untuk belajar. Selain itu dalam kegiatan membaca harus ada minat baca yang kuat dalam masing-masing setiap individu karena tanpa minat baca yang kuat tidak akan tercipta budaya baca. Hal ini sejalan dengan pendapat Nugroho (2015:30) yang menyatakan minat baca ditandai dengan kebiasaan seseorang dalam membaca.

Minat baca adalah keinginan dan kemauan secara sadar yang dilakukan seseorang untuk mengenal dan memahami huruf demi huruf dan kata demi kata yang dituangkan dalam bacaan sehingga dapat menangkap makna yang tertuang dalam tulisan tersebut. Dalman (dalam Nurhadi 2018:41) yang menyatakan "Minat baca merupakan dorongan untuk memahami kata demi kata dan isi yang terkandung dalam teks bacaan tersebut, sehingga pembaca dapat memahami hal-hal yang dituangkan dalam bacaan itu.

Minat baca juga diartikan suatu ketertarikan dan kemauan yang kuat yang disertai dengan perasaan senang terhadap suatu bacaan sehingga mejadi dorongan untuk melakukan kegiatan membaca. Sinabela (dalam Ameliah 2016: 2) mengartikan minat baca sebagai sikap positif dan adanya rasa ketertarikan dalam diri sendiri terhadap aktivitas membaca.

Minat baca perlu dikembangkan mulai sejak dini karena sangat berguna dan bermanfaat bagi anak ketika memasuki pendidikan sekolah dasar. Bagaimana tidak, dengan minat baca yang tinggi maka dapat mempermudah anak untuk memahami pembelajaran di sekolah. Selain itu juga, minat baca berpengaruh terhadap prestasi siswa di sekolah, dimana anak yang memiliki minat baca tingi cenderung prestasinya baik dan sebaliknya anak yang minat bacanya kurang cenderung prestasinya kuran baik. A.R Muslim dkk (2017:61) menyatakan bahwa 
minat baca berpengaruh terhadap prestasi belajar siswa sekolah dasar.

Berkaitan dengan hal di atas, studi awal dilakukan penulis sewaktu menjalankan program bimbingan membaca bagi siswa kelas 2 dan 3 yang pada pelaksanaan pengenalan lapangan persekolahan (PLP) di Sekolah Dasar Negeri 1 Seteluk 2020. Selama pelaksanaan terdapat 5 siswa yang belum lancar membaca, kemudian 2 diantaranya hanya sebatas mengenal huruf tanpa bisa menyambungkan huruf tersebut menjadi sebuah suku kata. Selama kegiatan berlansung siswa yang sering mengikuti kegiatan dengan antusias mengalami peningkatan. Sementara, salah satu siswa yang jarang mengikuti kegiatan dan lebih banyak bermain ketika pengadaan bimbingan cenderung tertinggal daripada teman-temannya yang lain. Hal ini menunjukkan bahwa kurangnya antusias siswa dalam mengikuti bimbingan menjadi penyebab rendahnya minat baca dari siswa tersebut.

Berdasarkan pemaparan permasalahan di atas maka peneliti tertarik untuk melakukan penelitian yang berjudul "korelasi antara minat baca dengan kemampuan membaca permulaan siswa kelas 3 Sekolah Dasar Negeri 1 Seteluk," sehingga dapat memberi gambaran tentang pentingnya minat baca dalam meningkatkan kemampuan membaca permulaan siswa yang merupakan dasar untuk menerima pembelajaran selanjutnya.

\section{METODE PENELITIAN}

Penelitian ini menggunakan pendekatan kuantitatif deskriptif yang bersifat korelasional dengan menggunakan jenis penelitian non eksperimen. Penelitian ini bertujuan untuk mencari korelasi antara variabel bebas $(\mathrm{X})$ minat baca dan variabel terikat (Y) kemampuan membaca permulaan. Bentuk penelitian ini dipilih dikarenakan sesuai dengan bentuk penelitian yaitu untuk menentukan korelasi sebab dan akibat antara minat baca dan kemampuan membaca permulaan siswa kelas III SDN 1 Seteluk. Populasi yang digunakan dalam penelitian ini adalah siswa kelas III SDN 1 Seteluk yang berjumlah 24 siswa. Adapun teknik pengambilan sampel pada penelitian ini yaitu sampling jenuh yang dimana semua populasi dijadikan sampel penelitian.

Teknik pengumpulan data yang digunakan adalah koesioner dan tes. Koesioner digunakan untuk mengumpulkan data minat baca Sedangkan tes digunakan untuk mengumpulkan data kemampuan membaca permulaan. Instrumen dalam penelitian ini terdiri dari instrumen minat baca dan instrumen tes kemampuan membaca permulaan.

Untuk uji coba instrumen dilakukan di SDN 2 Seteluk dengan jumlah sampel 30 siswa. Terdapat 13 item soal yang valid dan 2 item soal yang tidak valid. Item soal yang valid, kemudian akan dijadikan sebagai item instrumen pada penelitian dan akan dianalisis. Sementara item soal yang tidak valid, tidak diambil sebagai instrumen penelitian dan tidak perlu di analisis.

Teknik analisis data menggunakan analisis data statistik deskriptif untuk mendeskripsikan dan menggambarkan data yang terkumpul melalui teknik pengumpulan data dan uji korelasi untuk mencari korelasi (hubungan) antar kedua variabel dengan menggunakan korelasi pearson product moment.

\section{HASIL DAN PEMBAHASAN PENELITIAN \\ Hasil \\ Gambaran Minat Baca Siswa}

Data yang diperoleh melalui pengisian angket memiliki skor tertinggi yaitu 50 dan skor terendah yaitu 34. Berdasarkan hasil perhitungan dari data tersebut diperoleh data deskriptif sebagai berikut:

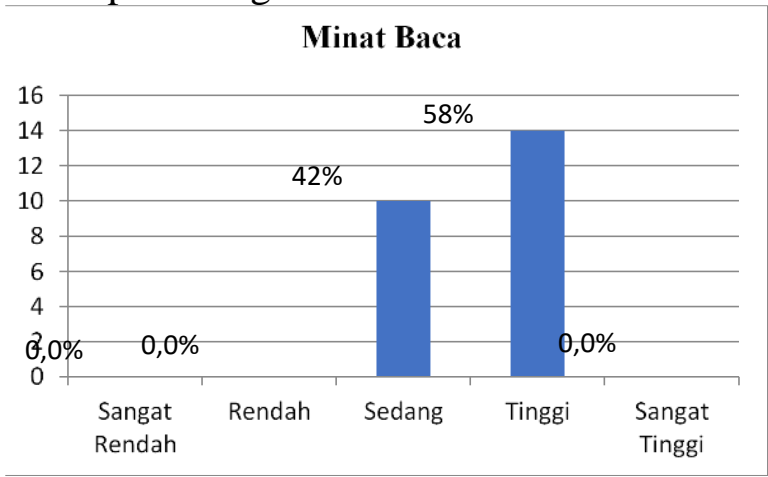

Diagram 1. Diagram Persentase Minat Baca 


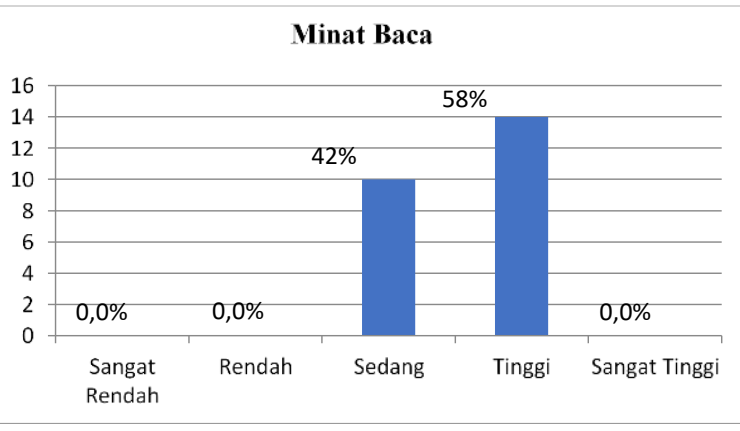

Dari tabel dan histogram di atas maka dapat diketahui bahwa Persentase minat baca menunjukan bahwa dari 24 siswa, yang memiliki minat baca sedang yaitu 10 orang dengan persentase $42 \%$. Sedangkan siswa dengan minat bacanya tinggi yaitu 14 orang dengan persentase $58 \%$. Dan siswa yang minat bacanya sangat rendah, rendah dan sangat tinggi tidak ada atau $0,0 \%$.

Dari uraian diatas dapat dijelaskan bahwa minat baca Siswa Kelas III SDN 1 Seteluk tinggi. Hal ini dapat dilihat dari persentase terbanyak berada pada kategori tinggi dengan persentase sebesar 58\%.

\section{Gambaran Kemampuan Membaca Permulaan Siswa}

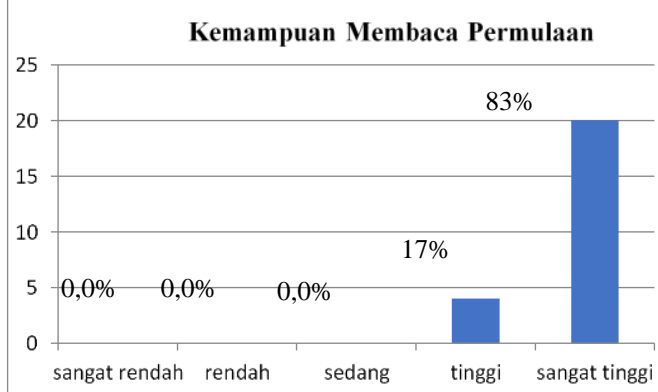

Dari tabel dan diagram di atas dapat dilihat persentase kemampuan membaca permulaan Siswa Kelas III Sekolah Dasar Negeri 1 Seteluk. Dimana 83\% kemampuan membaca permulaan sangat tinggi, $17 \%$ tinggi dan $0,0 \%$ kemampuan membaca siswa sangat rendah, rendah dan sedang. Dengan demikian dapat disimpulkan bahwa kemampuan membaca permulaan Siswa Kelas III Sekolah Dasar Negeri 1 Seteluk berada pada kategori sangat tinggi dengan persentase $83 \%$.

\section{Korelasi Minat Baca Dengan Kemampuan Membaca Permulaan}

Hasil korelasi pada penelitian ini diperoleh nilai 0,99 yang kemudian akan di konfirmasikan dengan tabel pedoman untuk memberikan interpretasi. Nilai 0,99 berada pada interval 0,80-1,00, maka dengan demikian dapat disimpulkan bahwa terdapat korelasi yang sangat kuat antara minat baca dengan kemampuan membaca permulaan Siswa Kelas III Sekolah Dasar Negeri 1 Seteluk.

Uji koefesien determinasi dilakukan untuk mengetahui tingkat kontribusi minat baca terhadap kemampuan membaca permulaan, memperoleh hasil sebesar $98,01 \%$. Hal ini berarti besar sumbangan tingkat minat baca terhadap kemampuan membaca permulaan siswa yaitu $98 \%$, sedangkan $2 \%$ dipengaruhi oleh faktor lainlain.

Uji $t$ dilakukan untuk mengetahui signifikansi atau hubungan variabel minat baca (X) terhadap kemampuan membaca permulaan (Y), diperoleh hasil $\mathbf{t}_{\text {hitung }}>$ $\mathbf{t}_{\text {tabel }}$ yaitu 4,95 $>2,074$ dengan taraf signifikansi 5\% sehingga dapat dikatakan bahwa penelitian tentang " korelasi minat baca dengan kemampuan membaca permulaan Siswa Kelas III SDN 1 Seteluk" signifikan.

\section{Pembahasan \\ Gambaran Minat Baca Siswa}

Minat baca merupakan suatu rasa kesukaan atau ketertarikan terhadap bahan bacaaan yang berasal dari dalam diri seseorang tanpa ada yang memaksa. Sejalan dengan pendapat Sinabela (dalam Ameliah 2016: 2) yang mengartikan bahwa minat baca sebagai sikap yang positif dan adanya rasa ketertarikan dalam diri sendiri terhadap aktivitas membaca. Membaca merupakan suatu kegiatan yang penting dilakukan dalam kehidupan sehari-hari. Dimana dengan banyak melakukan kegiatan membaca maka informasi dengan mudah didapatkan dan menambah pengetahuan baru. Ayuniar, dkk (2021: 26) juga memaparkan bahwa dengan membaca siswa dapat memahami bahasa tulis dan pembendaharaan kata.

Membaca merupakan salah satu jenis kemampuan berbahasa tulis, yang bersifat reseptif. Disebut reseptif karena dengan 
membaca seseorang dapat memperoleh informasi, memperoleh ilmu dan penetahuan baru serta pengalaman-pengalaman baru. Artinya semua yang diperoleh dari bacaan itu akan memungkinkan orang tersebut mampu mempertinggi daya pikirnya, mempertajam pandangnya dan memperluas wawasannya.

Adapun, dalam hal ini peneliti telah melakukan penelitian yang berkaitan dengan minat baca siswa. Dimana,data primer dalam penelitian ini berupa angket tentang minat baca (variabel X) siswa Kelas III Sekolah Dasar Negeri 1 Seteluk, dengan indicator minat baca menurut Crow and Crow (dalam Ameliah 2016: 19) terdiri atas perasaan senang, pemusatan perhatian, penggunaan waktu, motivasi untuk membaca, emosi dalam membaca, dan usaha untuk membaca sebagai acuan pembuatan soal.

Selanjutnya,item pernyataan minat baca menggunakan skala likert yang dikategorikan menjadi sangat tinggi, tinggi, sedang, rendah, dan sangat rendah. Berdasarkan perhitungan angket minat baca dengan teknik analisis statistik deskriptif diperoleh hasil yakni, dari 24 siswa yang dijadikan sampel penelitian terdapat 10 siswa yang memiliki kategori minat bacanya sedang atau sebesar 42\%. Dan 14 siswa yang memiliki minat bacanya tinggi yaitu sebesar 58\%. Sedangkan siswa dengan minat baca sangat tinggi, rendah, dan sangat rendah memiliki presentase $0,0 \%$, yang artinya tidak ada siswa kelas III SD Negeri 1 Seteluk yang berada dalam ketiga kategori tersebut.

Kemudian jika melihat nilai rata-rata hasil angket minat baca Siswa Kelas III Sekolah Dasar Negri 1 Seteluk sebesar 43,6. Dan persentase terbanyak berada pada kategori tinggi. Sehingga, dengan demikian dapat dikatakan bahwa minat baca Siswa Kelas III Sekolah Dasar Negeri 1 Seteluk tinggi dengan persentase $58 \%$.

\section{Gambaran Kemampuan membaca Permulaan Siswa}

Kemampuan membaca permulaan merupakan kemampuan yang dimiliki oleh siswa dimana mampu mengenal huruf, suku kata, dan mampu menghubungkan sebuah suku kata menjadi sebuah kalimat. Membaca permulaan diberikan pada kelas rendah yaitu I, II dan III. Terkait hal ini, Fauziah (2018: 175) Membaca permulaan diberikan pada kelas rendah dengan tujuan membina dasardasar mekanisme membaca yang akan mendasari kemampuan membaca selanjutnya.

Adapun, dalam penelitian ini kemampuan membaca permulaan dijadikan variabel terikat (y) yang diukur menggunakan tes.Tes tersebut dilakukan dengan meminta siswa maju satu-persatu untuk membaca teks sederhana. Kemudian memberikan penilaian menggunakan pedoman yang dipaparkan Angraeni dan Alpian (2020: 60-61) yang terdiri atas lafal, kelancaran, kejelasan suara, intonasi, dan menguasai tanda baca. Hasil tes tersebut dikategorikan menjadi 5 tingkatan yaitu sangat tinggi, tinggi, sedang, rendah, dan sangat rendah.

Berdasarkan hasil perhitungan tes membaca dengan menggunakan statistik deskriptif diperoleh hasil yakni, sebanyak 0,0\% berada pada kategori sedang, rendah, dan sangat rendah. Artinya tidak ada siswa yang hasil tes membacanya berada pada kategori tersebut. Dengan demikian, sebanyak $4(17 \%)$ siswa yang memiliki kemampuan membaca permulaan tinggi. Sedangkan sebagian besar siswa dengan presentase $83 \%$ yakni sebanyak 20 siswa. Persentase terbanyak berada pada kategori sangat tinggi, sedangkan jika melihat nilai rata-rata kemampuan membaca permulaan berada pada kategori sangat tinggi yaitu sebesar 89. Sehingga dengan demikian, dapat disimpulkan bahwa kemampuan membaca permulaan Siswa Kelas III SDN 1 Seteluk sangat tinggi.

\section{Korelasi Minat Baca dengan Kemampuan Membaca Permulaan}

Berdasarkan hasil perhitungan dengan rumus korelasi product moment pada penelitian ini menunjukkan bahwa korelasi antara minat baca dan kemampuan membaca permulaan dengan jumlah sampel 24 siswa diperoleh koefisien korelasi sebesar 0,99. Adapun, koefisien korelasi sebesar 0,99 ini berada pada kategori sangat kuat (lihat bab III tabel 3.7). Dimana, hal tersebut menunjukan 
adanya korelasi yang positif antara minat baca dengan kemampuan membaca permulaan. Artinya, setiap kenaikan pada variable bebas yakni minat baca akan mempengaruhi kenaikan pada kemampuan membaca permulaan sebagai variabel terikat. Hal ini sejalan dengan pendapat Ali dan Asrori (2014:53) mengartikan suatu variabel berkorelasi positif apabila variable tersebut bergerak sejalan, dimana kenaikan pada variabel $\mathrm{x}$ (bebas) secara konsisten akan diikuti oleh kenaikan pada varibael y (terikat). Adapun tingkat korelasi kedua variable dalam penelitian ini menunjukkan hasil korelasi yang sangat kuat karena nilai korelasi mendekati satu (+1) yakni berada pada interval 0,80-1 dalam table penafsiran koefisien korelasi.

Dari penjelasan di atas maka hipotesis alternative (Ha) diterima dan hipotesis nol (Ho) ditolak. Jadi hipotesis Ha yan berbunyi “ Ada korelasi minat baca dengan kemampuan membaca permulaan Siswa Kelas III SDN 1 Seteluk" diterima dan dapat dikatakan bahwa penelitian tentang "korelasi minat baca dengan kemampuan membaca permulaan Siswa Kelas III SDN 1 Seteluk" signifikan dilihat dari hasil uji t yang menunjukan bahwa $\mathbf{t}_{\text {hitung }}<\mathbf{t}_{\text {tabel }}$ yaitu 4,95 $>2,074$.

Kemudian, dalam analisis korelasi terdapat suatu angka yang disebut koefesien determinasi. Dimana besar angkanya adalah kuadrat dari koefesien korelasi $\left(r^{2}\right)$. Koefesien ini disebut sebagai koefesin penentu karena varian yang terjadi pada variabel dependen dipengaruhi oleh variabel independen. Maka koefesien yang disumbangkan oleh variabel bebas (X) terhadap variabel terikat $(\mathrm{Y})$ dalam penelitian ini adalah $98 \%$ dan $2 \%$ dipengaruhi oleh faktor lain-lain.

Minat baca merupakan kemauan atau keinginan yang kuat disertai dengan motivasi dan usaha untuk melakukan kegiatan membaca dengan senang hati tanpa ada paksaan dari orang lain. Menurut Rahim (2008: 10) menyatakan bahwa minat baca merupakan keinginan yang kuat disertai usaha-usaha seseorang untuk membaca. Keinginan dan kemauan siswa yang tinggi menjadi dorongan (motivasi) untuk melakukan kegiatan membaca. menurut Emda (Rahim 2018: 32) motivasi merupakan sesuatu yang esensial dalam proses belajar, tidak terkecuali belajar membaca. Karena tak jarang kita temukan siswa yang sebenarnya memiliki potensi akan tetapi memiliki motivasi yang kurang. Hal ini kemudian menyebabkan siswa tidak berusaha semaksimal mungkin untuk meningkatkan kemampuan membacanya. Selain itu, minat juga salah satu hal yang penting dalam meningkatkan kamampuan membaca siswa. Hal ini dikarenakan minat berjalan beriringan dengan motivasi, akan tetapi setingkat lebih tinggi dari motivasi. Bagaimana tidak, siswa yang memiliki minat yang lebih tinggi akan memiliki kesadaran yang tinggi untuk membaca karena memiliki ketertarikan yang kuat disertai dengan upaya untuk mengetahui dan mempelajari sesuatu lebih banyak sesuai dengan minatnya.

Berdasarkan pemaparan di atas dapat disimpulkan bahwa minat baca berpengaruh terhadap kemampuan membaca permulaan siswa. Sejalan dengan hasil penelitian yang dilakukan oleh Pramesti (2018: 287) yaitu minat baca merupakan salah satu faktor-faktor penghambat kemampuan membaca permulaan siswa. Hal ini dinyatakan bahwa minat baca merupakan hal penting yang mendasari keberhasilan membaca permulaan. Semakin tinggi minat baca siswa maka semakin tinggi juga kemampuan membaca permulaan siswa.

\section{KESIMPULAN}

Berdasarkan data yang di peroleh dari hasil analisis data yang telah dilakukan maka dapat disimpulkan bahwa terdapat korelasi positif yang kuat antara minat baca dengan kemampuan membaca permulaan siswa Kelas III Sekolah dasar Negeri 1 Seteluk. Hal ini dapat dilihat dari hasil perhitungan statistik deskriptif dan uji korelasi terhadap dua variabel tersebut. Hal ini kemudian diprkuat dengan hasil analisis korelasi pearson product moment yang memperoleh hasil koefesien korelasi sebesar 0,99. Artinya, bahwa minat baca dengan kemampuan membaca permulaan memiliki korelasi positif yang 
sangat kuat. Dimana nilai koefesien korelasi (r) mendekati 1.

\section{SARAN}

Hasil pnelitian ini diharapkan dapat menambah wawasan dan referensi yang seharusnya membuat pembaca lebih memperhatikan tentang pentingya minat dalam kemampuan membaca permulaan. Kedepannya, penelitian ini diharapkan menjadi bahan kajian berbagai kalangan terutama pihak sekolah agar lebih memperhatikan proses pembelajaran sehingga dapat meningkatkan minat siswa.

\section{DAFTAR PUSTAKA}

A.R, Muslim dkk. (2017). Pengaruh Minat Baca Terhadap Prestasi Belajar Siswa Sekolah Dasar.

Ali, Mohammad dan Asrori, Muhammad. (2014). Metodologi dan Aplikasi Riset Pendidikan. Jakarta: PT Bumi Aksara.

Ameliah, Rezki. (2016). Hubungan antara Minat Baca dengan Keterampilan Membaca Pemahaman Bagi siswa Kelas V MI Darul Istiqamah Kecamatan Pattalassang Kabupaten Gowa. Skripsi S1: Universitas Islam Negeri Alauddin Makasar.

Anggraini, Sri Wulan dan Alfian, Yayan. (2020). Membaca Permulaan dengan Team Games Tournament (TGT). Jawa Timur: CV. Qiara Media.

Ayuniar, Devi dkk (2021). Upaya Guru dalam Mengajarkan Keterampilan Membaca Siswa pada Masa Pandemi Covid-19 di SDN Gugus IV Kecamatan Pujut. Jurnal Progres Pendidikan.

Fauzia, H. (2018). Upaya Guru dalam Menembangkan Kemampuan Membaca Menulis Permulaan Siswa Kelas I MI. Jurnal Ilmiah Pendidikan Dasar.

Nugroho,Prasetyo. (2015). Pengaruh Minat Baca dan Kebiasaan Belajar Terhadap Prestasi Belajar Mata Pelajaran Konstruksi Bangunan Siswa Kelas $x$ Program Keahlian
Teknik Bangunan SMK Negeri Pringsurat. Skripsi S1: Universitas Negeri Yogyakarta.

Nurhadi.(2018). Teknik Membaca.Jakarta: PT. Bumi Aksara.

Pramesti, Fitria. (2018). Analisis FaktorFaktor Penghambat Membaca Permulaan pada Siswa Kelas I SD. Jurnal Ilmiah Sekolah Dasar.

Rahim, Farida. (2018). Pengajaran Membaca di Sekolah Dasar.Jakarta: PT. Bumi Aksara.

Rahmatika, Putri dkk. (2019). Metode Pembelajaran Mind Map Bercerita dan Gaya Kognitif, Penaruhnya Terhadap Kemampuan Membaca Permulaan. Jurnal Pendidikan Anak Usia Dini. 